\title{
Diversity in the Judiciary: A Conversation with Deanell Tacha*
}

Any discussion about diversity must first begin with what we understand that concept to mean. In the vernacular, diversity usually connotes differences in race and gender. But in my view, we need to think much more broadly than that. Diversity certainly encompasses those characteristics, but it also embraces divergent ethnic backgrounds, languages, religion, political views, life and professional experiences, and geographic areas-all of the features that make up the great mix of the American population.

But why do we care about what diversity means? And what is the importance of the concept to the judiciary? To answer these questions, we need to reach back a bit into our nation's history to nearly 250 years ago when a group of men (and they were indeed all men!) gathered in Philadelphia at the Constitutional Convention. This group had a remarkably idealistic - not to mention novel_-view that the people are sovereign. Not any branch of government, not any king or tyrant or dictator, but rather each of you — each of us! — holds the sovereign power in this nation. Think about how visionary and truly idealistic that is. The entire notion of the sovereignty of the people depends on whether every single one of us feels that government is fair, whether we think it is just, and whether we think we will be dealt with even-handedly under the law. The phrase engraved on the building that houses our Supreme Court"equal justice under the law"-has real importance.

The delegates to the Constitutional Convention realized that importance. The federal judiciary was designed under the Constitution to protect the people's sovereignty. We might say that the people are protected from government action by the Bill of Rights, but we need to remember that those rights do not exist unless someone enforces themand that is one of the roles of the federal judiciary. In this way, the third

\footnotetext{
* These remarks by Deanell Reece Tacha are taken from a forum co-sponsored by the League of Women Voters of Lawrence-Douglas County, the Dole Institute of Politics, and the University of Kansas School of Law. Bill Lacy, Director of the Dole Institute of Politics, moderated the session, which took place on September 30, 2010. At the time of her remarks, Deanell Reece Tacha was a Circuit Judge on the United States Court of Appeals for the Tenth Circuit. On June 1, 2011, she became Dean at Pepperdine University School of Law.
} 
branch of government stands for your sovereignty and must represent the ideal that government is fair and can be trusted.

How does diversity fit into this framework? On this point, it is interesting to consider the hearings on recent Supreme Court nominees. What do the nominees open the floor with? Not by explaining how he or she attended the best law school in the country, or made certain grades, or achieved various milestones in his or her career. Instead, Justice Ginsburg began by stating, "I am ... a Brooklynite, born and bred-a first-generation American on my father's side, barely second-generation on my mother's." Justice Alito discussed the discrimination his ItalianAmerican father faced during the Depression. ${ }^{2}$ Judicial nominees emphasize these life experiences because it is so important to emblazon in the American people's mind the notion that "I am one of you, and I understand your plight. My life experiences are similar to some of your life experiences." When the judiciary is composed of people who all look the same way, speak the same way, and identify the same way, then there are many, many people in our country who don't feel like the life experiences — and the resultant mindset — of the judge are the same as their own.

This is not about the outcomes of cases. Instead, diversity is about bringing together collective knowledge, born from an array of experiences, in order to ensure the judiciary and its decisions are respected and followed. I often think about the Supreme Court's decision in Bush v. Gore ${ }^{3}$ and how our nation responded to it. Certainly, not everyone agreed with that decision, and many people questioned how it was decided. But as a collective whole, we accepted the decision as the final word on the matter: there was no fighting in the streets, and we more or less went about our personal business that day. Without this level of institutional respect-which is dependent, in part, on the perception that the judicial branch is at least somewhat reflective of us as individuals — such a reaction would have been unimaginable.

Relatedly, diversity on the bench enriches the deliberative process. Recall the recent Supreme Court decision in Safford Unified School

1. Nomination of Ruth Bader Ginsburg, to Be an Associate Justice of the Supreme Court of the United States: Hearings Before the S. Comm. on the Judiciary, 103d Cong. 49 (1st Sess. 1993) (statement of Hon. Ruth Bader Ginsburg, Circuit Court Judge, U.S. Court of Appeals for the District of Columbia, to Be Associate Justice of the Supreme Court of the United States).

2. Confirmation Hearing on the Nomination of Samuel A. Alito, Jr. to Be an Associate Justice of the Supreme Court of the United States: Hearing Before the S. Comm. on the Judiciary, 109th Cong. 54-55 (2d Sess. 2006) (statement of Samuel A. Alito, Jr., of N.J., Nominee to Be an Associate Justice of the Supreme Court of the United States).

3. 531 U.S. 98 (2000). 
District No. 1 v. Redding. ${ }^{4}$ A thirteen-year-old girl had been subjected to a strip search at school because school officials thought she might be hiding prescription drugs in her undergarments. ${ }^{5}$ During oral argument, there were some statements from the bench comparing the search to simply changing clothes for gym class. ${ }^{6}$ Justice Ginsburg, who was the only woman on the Court at that time, disagreed with that analogy. ${ }^{7}$ Later, she explained that her male colleagues did not understand the girl's humiliation because they had never themselves been a thirteenyear-old girl. ${ }^{8}$ Certainly, Justice Ginsburg's views were considered as the Court deliberated after that argument!

It is clear, then, that diversity matters. It is important. And to that end, we must consider how the varying methods of selecting judges in this country affect the diversity of the judiciary. I can speak first about the federal system, given my personal experience as a federal judge. Without advocating for one approach or another, I can say that the federal system of appointing judges and giving them lifetime tenure safeguards an integral component of diversity: diversity of thought and of opinion. Having life tenure, not having to run for election, and not being dependent-indeed, ignoring - the political winds of the time is terribly important to an independent judiciary. Being able to maintain a lifetime salary is also a key component of this ideal. When Congress doesn't like what I do, it can't punish me by taking away my income. That is a terrible temptation in the political process-the notion that if you don't like what a certain person or agency or judge did, then just cut their budget. And that, of course, hampers the independence of the judiciary and hampers our ability to do our work. So in my view, the federal system allows for the kind of intellectual acuity that is entirely freed from the political process.

I have a story I like to tell when discussing the importance of an independent judiciary. I went to Albania in the early 1990s after that nation underwent a revolution of the sort seen in many former communist countries around that time. Prior to that, Albania had been one of the most repressive dictatorships in the world; its allies included Haiti, Cuba, and to some extent North Korea. I traveled there as part of

4. 129 S. Ct. 2633 (2009).

5. Id. at 2638.

6. Transcript of Oral Argument at 44-45, Redding, 129 S. Ct. 2633 (No. 08-479), available at http://www.supremecourt.gov/oral_arguments/argument_transcripts/08-479.pdf.

7. Id. at $45-46$.

8. Joan Biskupic, Ginsburg: The Court Needs Another Woman, USA TODAY, May 6, 2009, at $1 \mathrm{~A}$. 
one of the very first Western legal delegations to help the country create a constitution. The delegation included another federal judge-Judge Higginbotham of the Fifth Circuit - two constitutional scholars, and the president of the American Bar Association. We were given draft constitutional provisions that Albania's government wanted us to work through with its leaders. One of these draft provisions was a ban on ethnic minority political parties, which, given the political climate in that geographic area during that time, was a potentially lightning-rod issuenot to mention a concept totally foreign to the United States' and other democracies' systems of government.

The night before we met with our Albanian counterparts, we took a look at this ban on ethnic political parties and we decided we did not think we should start with that in the morning-we just did not think that was the first place to jump off on this endeavor! So we began our discussions the next day with the plain-vanilla constitutional concepts of Article I, Article II, and Article III, describing the legislative, executive, and judicial powers. And then the young, newly elected Attorney General of Albania stuck his hand up and asked, "What would judges in your country do with this ban on ethnic minority political parties?" Well, Judge Higginbotham and I cavalierly responded, "Ha! Easy-it would be unconstitutional." They started flipping through their little Albanian versions of the American constitution trying to figure that out. So we explained the principles of freedom of association, freedom of speech, and an independent judiciary that determines the constitutionality of laws passed by Congress and signed into law by the President. The room got incredibly quiet. The same newly elected Attorney General of Albania said, "Well, what if the President doesn't like what you say?" Again cavalierly, we answered, “Tough.” We explained judicial review and the independence of the third branch. You could have heard a pin drop in that room. Finally, he got up his courage and he said, "But what if the military comes after you?" You want to see a couple of old, curmudgeonly federal judges brought to tears-you should have seen us at that moment. We realized in that one simple question what we take for granted. I can assure you there isn't a judge in the nation that worries about whether the United States military is coming to get them. And that is because we as a nation have a longstanding and respected tradition of following the dictates of the courts. So to circle back to the issue of how we select our judges, I think it is very, very important that we do so in a way that frees them from the political wind of the day. The federal system achieves this goal quite admirably.

Now, that said, I understand that it is inherent in our federal system that the states make different choices in different ways. Very generally 
speaking, there are two ways that state judges take the bench: by appointment or through a general election. Kansas judges are usually appointed, although some district court judges are elected. For those judges who go through the nomination process, a judicial nominating commission made up of both lawyers and nonlawyers recommends two or three candidates to the governor, who then selects one person from that list to fill a judicial vacancy. ${ }^{9}$ Those judges are then subject to a retention vote every four years or every six years for our Supreme Court Justices. $^{10}$

Research regarding the effect of the various state-selection methods on the diversity of that state's judiciary appears to be mixed, although some studies have suggested that the appointment method may play a role in bringing an array of voices to the bench. ${ }^{11}$ But regardless of the method, it is clear that neither the federal courts nor the state courts accurately reflect the faces and experiences of our population. A recent study of the highest courts in all fifty states showed that minorities account only for about twelve percent of judges, and women make up about thirty-one percent. ${ }^{12}$ Only one judge identified himself or herself as American Indian, and no judges self-identified as Middle Eastern or Southeast Asian. ${ }^{13}$

The impact of an appointment method versus an elective method may play a greater role in the independence of the judiciary-which, as I explained a little earlier, should also be considered in our discussion of diversity. Justice O’Connor, who is a very good, dear friend of mine and just visited here last spring, is quite a proponent of the appointment approach to judicial selection. She has been busy going around the country discussing the merits of that type of system. I think, in part, her

9. In the case of judges and justices on the Kansas Court of Appeals and Kansas Supreme Court, the Supreme Court Nominating Commission sends the names of three individuals to the Governor. Court of Appeals, KANSAS JUDICIAL BRANCH, http://www.kscourts.org/kansascourts/court-of-appeals/default.asp (last visited Apr. 3, 2011); Nominating Commissions, KANSAS JUDICIAL BRANCH, http://www.kscourts.org/appellate-clerk/nominating-commission/default.asp (last visited Apr. 3, 2011); Supreme Court, KANSAS JUDICIAL BRANCH, http://www.kscourts.org/kansascourts/supreme-court/default.asp (last visited Apr. 3, 2011). For district court judges, a judicial nominating commission in that district recommends two or three individuals to the Governor. Nominating Commissions, supra.

10. Nominating Commissions, supra note 9.

11. See Malia Reddick, Michael J. Nelson, \& Rachel Paine Caufield, Am. Judicature SOC'y, EXAMINING Diversity on STATE COURTS: HOW DOES THE JUdiCial SELECTION ENVIRONMENT ADVANCE—AND INHIBIT—JUDICIAL DIVERSITY? 7 (2010).

12. Gregory L. Acquaviva \& John D. Castiglione, Judicial Diversity on State Supreme Courts, 39 SETON HALL L. REV. 1203, 1214, 1223 (2009).

13. Id. at 1217. 
experience is like mine: when you travel the world and witness emerging republics of the world, you realize very deeply that the mainstay of any free people is an independent judiciary insulated from the tides of politics.

I have my own take on what might be done to improve diversity on the bench. Whether we are talking about federal judges or state judges, a system of appointment or one of elected judges, in order to increase the diversity of our judiciary the public has to want it and call out for it. And the public will only do so if it understands the importance of that diversity. So I applaud tonight's sponsors for taking steps to educate our citizenry through forums like this one. In addition, we might consider who comprises our local judicial nominating commissions. Justice O'Connor has suggested that those commissions should be a little more diverse themselves, and I think she may have a point there. When the people who select judges come from varying backgrounds, I think that probably the chances are somewhat higher that the nominees will be similarly diverse.

Finally, I cannot underscore enough the importance of supporting and recruiting diverse individuals. I will tell my own story here. Perhaps some of you know this, but I didn't want to be a judge! I loved being Vice Chancellor for Academic Affairs. I thought KU was the place I wanted to spend my life. I liked my basketball tickets! But I began to get the telephone calls, and I kept hearing, "You need to take this position. You need to step up. You need to do it.” Because I was a woman in the profession at a time when it was still not exactly commonplace and because I had reached a point in my career where I was considered qualified by the people who have the say in those things, I was recruited for this judicial position. And I said no many times. I couldn't visualize myself as a judge. I had never known a woman judge. When I graduated from law school in 1971, there were only six Article III women judges - and that's nationwide. ${ }^{14}$ So I just couldn't see myself in that role.

It was a very difficult decision, and I had to be convinced that it was the right thing. This is why I consider recruitment and support to be such an integral component of any discussion about diversity. To this day, there are a lot of people who don't visualize themselves as judges for the same reasons that it was hard for me to do so. They have not met people like them who are in the judiciary. They have not had law professors

14. See Mary L. Clark, One Man's Token Is Another Woman's Breakthrough? The Appointment of the First Women Federal Judges, 49 VILL. L. REV. 487, 492-93 (2004). 
who are like them. They haven't even seen lawyers who are like them. To the extent we can encourage these highly qualified people to reach for positions in the judiciary, we must do so. Certainly, that played an enormous role in my experience.

So to each of the law students and lawyers here this evening, I encourage your participation in public service. I laud your current contributions to our profession. And as members of the profession, I emphasize that we each have a very important role in ensuring the diversity of our judiciary. A diverse judiciary is a respected and independent one, and one that will safeguard the American republic. Thank you for working so hard to maintain the very best of our nation's ideals. 